\title{
Sciendo
}

\section{QUALITY OF LIFE IN HEALTHY CHILDREN IN LATVIA}

\author{
Sandra Tapin,a ${ }^{1, \#}$ Kristīne Vasīe $^{1}$, Valda Bebre-Putka ${ }^{1}$, Elza Gārša ${ }^{1}$, \\ and Ingrīda Rumba-Rozenfelde 1,2 \\ ${ }^{1}$ University of Latvia, Faculty of Medicine, 19 Raina Blvd., Rīga, LV-1586, LATVIA \\ ${ }^{2}$ Children's Clinical University Hospital, 45 Vienības Avenue, Rīga, LV-1004, LATVIA \\ \# Corresponding author, sandra.feierabende@gmail.com
}

Contributed by Ingrīda Rumba-Rozenfelde

\begin{abstract}
In Latvia, no studies on the quality of life (QoL) of healthy children have been conducted. Determining the quality of life of children is an essential part of evaluating the health status of children. The subjective assessment of the individuals about their quality of life provides an opportunity to evaluate the quality of life of the population in the public health sector. The aim of this crosssectional study was to evaluate the quality of life of healthy children and adolescents in Latvia in the age group from 8 to 18, as well as to compare the answers between children and their parents living in Latvia. This study also gave an opportunity to compare the results of children and their parents living in Europe. Quality of life measurements were obtained using the KIDSCREEN-52 questionnaire, which was filled out by 100 healthy children/adolescents and 100 of their parents/guardians. The quality-of-life questionnaire consisted of ten dimensions. When evaluating the quality of life of children and adolescents by gender, no statistically significant difference was found in Latvia $(p>0.05)$. There was no statistically significant difference $(p>0.05)$ between children of 8 to 11 years of age and children of 12 to 18 years of age. A statistically significant difference was found between the 8 to 11 and 12 to 18-year-old groups of young healthy children in some dimensions. In the response dimensions, self-perception ("SEL") and emotions ("EMO"), their QoL was significantly higher $(\mathrm{p}<0.05)$ in the age group from 12 to 18 years healthy children than in the age group of 8 to 11 years. Differences in child/adolescent quality of life results between Latvia and Europe were not statistically significantly different in all $10 \mathrm{HRQOL}$ dimensions ( $\mathrm{p}>0.05)$.
\end{abstract}

Keywords: health, questionnaire.

\section{INTRODUCTION}

Estimation of the quality of life of children is an essential part of the assessment of the health status of children. Quality of life (QoL) measurements are seldom used for assessing health of individuals or in planning of public health programmes. In Latvia, no studies on the quality of life of healthy children have been conducted until now.

Paediatrics is the only sector of medicine that is dedicated to the health and well-being of children and teens and whose goal is to ensure life fulfilment and development in several aspects of quality of life. For a child's growth, not only are organ systems and biological processes essential, but environmental, social, and political factors also play important roles in promoting the health and well-being of the child (Kliegman et al., 2016). The World Health Organisa- tion (WHO) defines health as the condition of a person, consisting of complete physical, mental, and social wellbeing, not just a lack of illness or disability (Constitution..., 2002).

The guidelines in Latvia, according to the standards of preventive examinations and examinations of children established by the Ministry of Health and the National Health Service, state that for children aged 7 to 18 years, preventive examinations should be performed once a year in the doctor's practice (National Health Service, Republic of Latvia, 2018). During the preventive examination, it is important not only to objectively examine the child and listen to the complaints or observations of the parents, but also to listen to the child's subjective opinion about their health and well-being. We can evaluate health-related quality of life 
(HRQoL) by hearing the child's and teenager's opinion, and by summarising the results obtained at a larger scale, therefore determining the QoL for a large group of the population. The subjective assessment of each child is a part of the indicators of health of society, which shows improvement or regression of QoL in the population. The QoL assessment displays a person's perception of health, well-being, emotional health, and various life factors that create joy (Ravens-Sieberer et al., 2005).

To measure the quality of life, the concept of health-related quality of life (HRQoL) was created, which can display, how the quality of life affects both physical and mental health. The KIDSCREEN-52 survey was created to measure the quality of life in ten HRQoL dimensions (RavensSieberer et al., 2005; KIDSCREEN Group Europe, 2006).

The aim of the study was to conduct a quality of life assessment in children and adolescents of age between 8 to 18 years in Latvia using the questionnaire KIDSCREEN-52 (Ravens-Sieberer et al., 2005; KIDSCREEN Group Europe, 2006).

\section{MATERIALS AND METHODS}

This cross-sectional study was conducted at a primary health centre. Patients and their parents were asked to fill out a survey that was intended for healthy children and teenagers aged 8 to 18 years. In this study, data on the quality of life of healthy children in Latvia were obtained from Vidzeme region and Rīga District.

The data were collected between December 2018 and April 2019. In our study we used KIDSCREEN-52 surveys for children and teenagers, and also separate surveys for the parents of these children. The surveys were aimed to assess the parents' perception of their children's quality of life (Ravens-Sieberer et al., 2005; KIDSCREEN Group Europe, 2006). In total, 100 children and 100 parents were involved in the study. The study was conducted in the form of an anonymous questionnaire. Respondents were explained the purpose of the work, their participation, and their right to refuse taking part in the study.

The questionnaire included ten various dimensions related to quality of life:

1. Physical well-being (PHY) - questions about physical health, well-being during physical activities;

2. Psychological well-being (PWB) - questions about a child's satisfaction with life, cheerfulness, and general feelings;

3. Moods and emotions (EMO) - questions about well-being in everyday life, emotions;

4. Self perception (SEL) - questions about self-assessment;
5. Autonomy (AUT) - questions about how the children make decisions about their free time, assessment of the amount of time devoted to themselves, their ability to spend time with friends and outdoors;

6. Parent relations and home life (PAR) - questions about the relationship between the child and parents;

7. Financial resources (FIN) - questions about the financial security of the child;

8. Peers \& social support (SOC) - questions about the relationship between the child and their friends, trust;

9. School environment $(\mathrm{SCH})-$ questions about the child's well-being and emotions at school;

10. Bullying (BUL) - questions about whether the child feels insulted or humiliated by other children.

The rating system consisted of response categories: No; A little; Medium; Very; More than very.

Or alternatively: Never; Rarely, Quite often (Q. Often), Often, Always.

Applied statistical methods: Every response option was rated by a score. For example, the answer "No" was rated as 1 , "a little" was rated as 2 , etc., in that way quantifying the answers of children, adolescents, and their parents. The data were processed and analysed using MS Excel and IBM SPSS Statistics Version 25. For quantitative data (the mean, minimum, and maximum values, standard deviations) $95 \%$ confidence intervals were calculated. All mean results also showed " \pm " standard deviations.

We applied the Cronbach-alfa $(\mathrm{K} \alpha)$, Kolmogorov-Smirnov test, Mann-Whitney test, one sample T-test; Chi-square test, and odds ratio calculations; the results were considered as statistically significant if $p$ was less than $0.05(p<0.05)$.

\section{RESULTS}

There was no statistically significant difference between the quality-of-life assessments of healthy children and their parents $(p>0.05)$ in Latvia in all ten dimensions (Fig. 1).

There was no statistically significant difference between genders in Latvia $(p>0.05)$ for the quality of life of children and adolescent (Table 1).

A statistically significant difference was found between 8 to 11-year-old and 12 to 18-year-old healthy children in Latvia in the response in dimensions "SEL" and "EMO" $(p<$ $0.05)$. The mean value of quality of life assessment in the dimension "SEL" for children from 8 to 11 years was 15.04 with $\mathrm{SD} \pm 0.98$, and for children from 12 to 18 years $24.73 \pm 0.96$. In EMO, the mean quality of life assessment for children from 8 to 11 years of age was $15.65 \pm 0.74$, and for children from 12 to 18 years $-24.88 \pm 0.86$. In the 


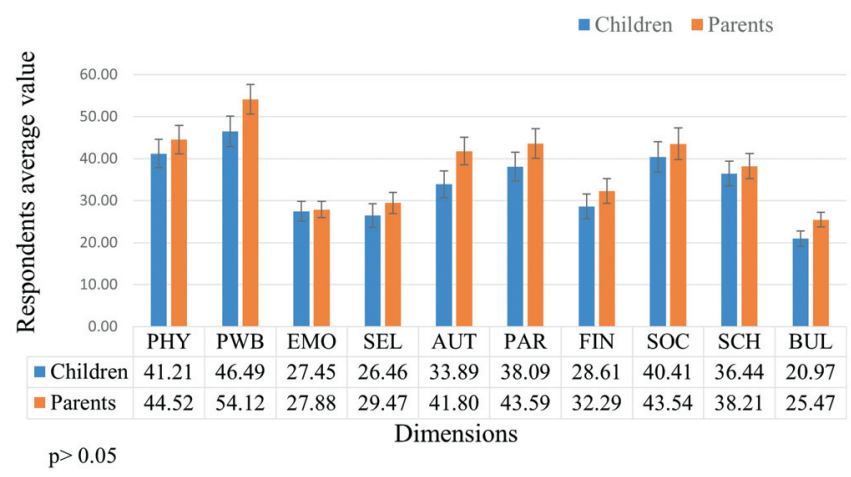

Fig. 1. Quality-of-life assessment between children and parents.

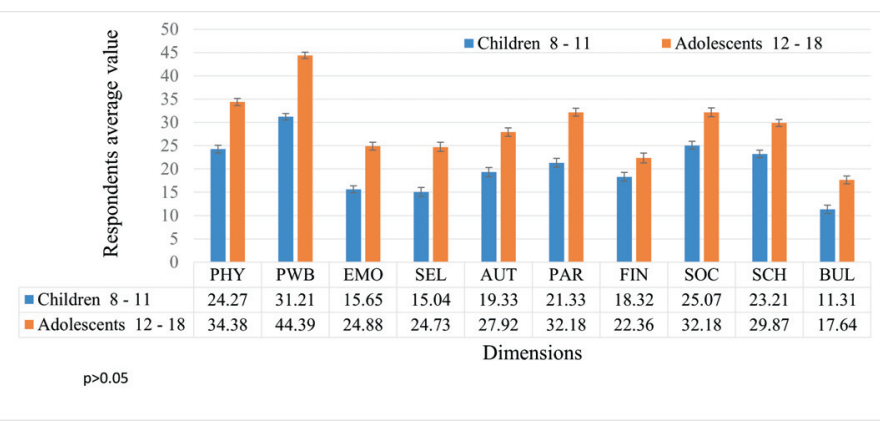

Fig. 2. Average values of children's quality of life by age group in KIDSCREEN-52 questionnaire 10 dimensions.

Table 1. Statistical analysis of the quality of life of girls and boys using the results of the KIDSCREEN-52 survey

\begin{tabular}{|c|c|c|c|c|c|c|c|c|c|c|}
\hline \multirow[t]{3}{*}{ Dimension } & & & & & & & & \multicolumn{3}{|c|}{ Statistical analysis } \\
\hline & \multicolumn{4}{|c|}{ Girls } & \multicolumn{3}{|c|}{ Boys } & & \multirow[t]{2}{*}{$\mathrm{U}$} & \multirow[t]{2}{*}{$\mathrm{P}_{\mathrm{U}}$} \\
\hline & mean & SD & \multicolumn{2}{|c|}{ CI 95\% } & mean & SD & CI 95\% & & & \\
\hline PHY & 30.82 & 0.83 & 27.67 & 34.41 & 27.16 & 0.82 & 24.03 & 30.79 & 1.184 & 0.760 \\
\hline PWB & 44.45 & 0.64 & 40.98 & 48.26 & 31.02 & 0.77 & 27.65 & 34.87 & 1.11883 & 0.448 \\
\hline EMO & 20.46 & 0.92 & 18.27 & 23.14 & 18.78 & 0.79 & 16.82 & 21.23 & 1.06542 & 0.249 \\
\hline SEL & 20.56 & 1.04 & 18.00 & 23.38 & 16.77 & 1.09 & 14.37 & 19.84 & 1.0874 & 0.372 \\
\hline AUT & 25.39 & 0.95 & 22.44 & 28.84 & 22.52 & 0.93 & 19.63 & 25.99 & 1.1309 & 0.504 \\
\hline PAR & 28.39 & 0.93 & 25.18 & 32.09 & 25.49 & 0.86 & 22.33 & 29.20 & 1.18733 & 0.785 \\
\hline FIN & 20.93 & 1.06 & 18.27 & 24.15 & 19.62 & 0.96 & 17.06 & 22.78 & 1.16833 & 0.702 \\
\hline SOC & 30.11 & 0.95 & 26.65 & 34.07 & 27.39 & 0.85 & 24.15 & 31.16 & 1.07216 & 0.374 \\
\hline $\mathrm{SCH}$ & 26.41 & 0.85 & 23.71 & 29.56 & 26.14 & 0.79 & 23.3 & 29.47 & 1.03233 & 0.205 \\
\hline BUL & 15.77 & 0.85 & 14.21 & 17.78 & 13.87 & 0.89 & 12.28 & 16.01 & 1.1255 & 0.542 \\
\hline
\end{tabular}

PHY, physical well-being; PWB, psychological well-being; EMO, moods and emotions; SEL, self-perception; AUT, autonomy; PAR, parent relations and home life; FIN, financial resources; SOC, peers \& social support; SCH, school environment; BUL, bullying

other eight HRQoL dimensions no statistically significant differences in the results were observed $(p>0.05)$ (Fig. 2).

Child/adolescent quality of life results between Latvia and Europe did not show statistically significant differences in all ten HRQoL dimensions ( $p>0.05)$ (Table 2).

Table 2. Quality of life based on KIDSCREEN-52 questionnaire responses by children and adolescents in Latvia compared to Europe

\begin{tabular}{|c|c|c|c|c|c|}
\hline \multirow[t]{3}{*}{ Dimension } & \multicolumn{4}{|c|}{ Children and adolescents aged 8 to 18 years } & \multirow{3}{*}{$\begin{array}{l}\text { One sample } \\
\text { T-test } p \\
\text { value }\end{array}$} \\
\hline & \multicolumn{2}{|c|}{ Latvia } & \multicolumn{2}{|c|}{ Europe } & \\
\hline & Mean & SD & Mean & SD & \\
\hline PHY & 41.21 & 3.37 & 69.46 & 19.29 & 0.159 \\
\hline PWB & 46.49 & 3.63 & 76.56 & 18.31 & 0.153 \\
\hline EMO & 27.45 & 2.34 & 78.50 & 17.23 & 0.286 \\
\hline SEL & 26.46 & 2.79 & 73.34 & 20.90 & 0.280 \\
\hline AUT & 33.89 & 3.19 & 72.76 & 20.97 & 0.222 \\
\hline PAR & 38.09 & 3.44 & 78.91 & 19.30 & 0.214 \\
\hline FIN & 28.61 & 2.91 & 73.74 & 19.43 & 0.264 \\
\hline SOC & 40.41 & 3.62 & 66.39 & 20.90 & 0.152 \\
\hline $\mathrm{SCH}$ & 36.44 & 2.99 & 88.90 & 16.53 & 0.252 \\
\hline BUL & 20.97 & 1.82 & 71.35 & 26.89 & 0.318 \\
\hline
\end{tabular}

For abbreviations see Table 1
There were no statistically significant differences between Latvian and European parents regarding their assessment of children's quality of life, and the mean values across all ten HRQoL dimensions showed statistically similar results $(p>$ 0.05) (Table 3).

Table 3. Quality of life according to KIDSCREEN-52 survey data provided by parents in Latvia and the Europe

\begin{tabular}{c|c|c|c|c|c}
\hline \multirow{2}{*}{ Dimension } & \multicolumn{4}{|c|}{ Parents responses } & \multirow{2}{*}{$\begin{array}{c}\text { One sample } \\
\text { T-test p } \\
\end{array}$} \\
\cline { 2 - 5 } & \multicolumn{2}{|c}{ Latvia } & \multicolumn{2}{c}{ Europe } & value \\
\cline { 2 - 5 } & Mean & SD & Mean & SD & \\
\hline PHY & 44.52 & 3.36 & 72.08 & 17.75 & 0.148 \\
PWB & 54.12 & 3.56 & 74.94 & 15.40 & 0.102 \\
EMO & 27.88 & 1.96 & 81.38 & 13.39 & 0.290 \\
SEL & 29.47 & 2.51 & 76.72 & 16.75 & 0.267 \\
AUT & 41.80 & 3.26 & 75.32 & 18.01 & 0.177 \\
PAR & 43.59 & 3.50 & 77.70 & 15.60 & 0.175 \\
FIN & 32.29 & 2.95 & 66.71 & 25.57 & 0.213 \\
SOC & 43.54 & 3.79 & 67.93 & 18.09 & 0.137 \\
SCH & 38.21 & 3.01 & 69.43 & 17.87 & 0.180 \\
BUL & 25.47 & 1.75 & 88.43 & 15.15 & 0.321
\end{tabular}

For abbreviations see Table 1 


\section{DISCUSSION}

So far, the quality of life of children and teenagers in Latvia has not been studied. In Europe and other countries of the world, studies on assessment of the quality of life of only healthy children are limited and generally are included in studies as control groups, rarely gathering information about healthy children QoL.

When using data from questionnaires, internal consistency on dimension issues is of great importance, and is estimated by Cronbach $\operatorname{Alpha}(K \alpha)$. In Norway, in a study where the "KIDSCEEN- 52" questionnaire was used, $K \alpha$ in all ten dimensions ranged from 0.80 to 0.88 , indicating good internal consistency (Haraldstad et al., 2011). In our study Ka was below 0.6, which showed that in the QoL dimension "SEL" had low internal consistency. However, in this dimension of questions, a statistically significant difference was found between healthy children aged 8-11 and 12-18 in Latvia. In the response measurements, "SEL" and "EMO" showed statistically important differences that indicated that children and teenagers in the age group from 12 to 18 years evaluated their quality of life higher than healthy children in Latvia from 8 to 11 years in these two dimensions.

No statistically significant difference was found $(p>0.05)$ in questionnaire responses between girls and boys in the age groups from 8 to 11 years and 12-18 years. In Colombia, estimates of the quality of life of children in the age groups from 8 to 10 years and from 15 to 18 years were compared. Statistically significant differences were obtained in the groups for questions "PWB", "PHY", "EMO", "SEL", "SCH", noting that teenagers aged 15-18 years reported higher quality of life than young children aged 8 to 10 years (Jaimes-Valencia et al., 2019). In Spain, children were divided into age groups from 8 to 11 years old, from 12 to 15 years old and from 16 to 18 years old according to the quality-of-life measurement. The study evaluated the responses of children in the "EMO", "PHY" and "PWB" quality of life measurements and showed that the highest quality of life measurements were in the age group from 8 to 11 years (Barrio et al., 2018). The grouping of children by age gives a more accurate view on the quality of life of children and teenagers and makes it easier to see changes in children and teenagers at various phases of growth and development.

There is no statistically significant difference in the quality of life of children and teenagers Latvia between gender $(p>$ 0.05). In a study in Australia, there was a statistically significant difference in the "PHY", "PWB", and "PAR" quality of life measurements between genders. The responses by the boys in the quality-of-life measurements were higher than those of girls, indicating that the quality of life of boys was significantly higher (Meade et al., 2015). To compare the differences in the quality of life between age and gender groups in Europe in 12 countries, a study was conducted using the KIDSCREEN-52 survey. The study compared responses between 8 -year-old and 18-year-old children. The results showed that in the measurement of "PHY" questions, 8-year-old boys had significantly higher quality of life scores than girls. Similarly, in the "PHY" dimension, a statistically significant difference was observed between 18-year-old young boys and girls, but here the reported HRQoL by girls in this dimension was higher (Michel et al., 2009). The results in Latvia indicate that there were no significant differences between genders of the respondents in HRQoL ratings.

There was no statistically significant difference between how children and their parents valued the quality of life of their children in Latvia $(p>0.05)$, and the average scores in all ten HRQoL dimensions in both the child and the parent groups showed similar results. In Greece, a study was conducted on the quality of life of teenagers with idiopathic sclerosis. The goal was to determine if the quality-of-life scores were the same between children and their parents. In the group of questions "PAR" there was no significant difference between the assessments of children and parents (Kontodimopoulos et al., 2018). In another study in Greece, the results between parents and their children who were diagnosed with epilepsy differed. In the "PHY" and "SCH" dimensions, the reported quality of life by children was significantly lower than the estimates provided by their parents, indicating differences of opinion in the assessment of the quality of life (Bompori et al., 2014).

Studies on the differences in the quality of life between children and parents are mainly designed to compare assessments of the quality of life between chronically ill children and their parents. However, in our study in Latvia, the assessment of the quality of life by healthy children did not significantly differ from the responses provided by parents about the quality of life of their children. Therefore, the comparison with European and world data is limited. Indicators of the quality of life of children and teenagers in Latvia have not been compared with data from Europe until now. Statistical analysis of the data of the KIDSCREEN-52 survey on the quality of life of children/teenagers in Latvia showed no significant differences compared to Europe, in all ten HRQoL dimensions $(p>0.05)$. Statistical analysis of the responses provided by Latvia and the European parents on the quality of life of their children also not show a significant difference in all $10 \mathrm{HRQOL}$ dimensions $(p>0.05)$.

Research in the world about the quality of life of healthy children currently is limited. In this study, data on the quality of life of healthy children in Latvia were obtained from Vidzeme and the Rìga region. Therefore, for further research and to confirm the obtained data, it is necessary to obtain an assessment of the quality of life of healthy children from other regions of Latvia.

\section{CONCLUSIONS}

1. In our study of healthy children/adolescents and their parents, there were no significant differences between quality-of-life assessments of how children rate their QoL and how their parents value their children's QoL across all dimensions of the KIDSCREEN-52 questionnaire $(p>0.05)$. 
2. In quality of life in Latvia, no statistical difference was found between males and females $(p>0.05)$.

3. According to responses to the KIDSCREEN-52 survey, no statistically significant difference $(p>0.05)$ was found between age groups (8-11 years and 12-18 years) in eight dimensions, but in two question categories "About myself" and "General mood" there were significant differences $(p<$ $0.05)$.

4. The assessment of quality of life in healthy children/adolescents in Latvia and Europe was similar $(p>0.05)$. Also, no significant difference $(p>0.05)$ was found between the answers given by Latvian parents about the quality of life of their healthy children compared to the answers given by European parents.

\section{REFERENCES}

Barrio, J., Cilleruelo, M. L., Román, E., Fernández, C. (2018). Health-related quality of life in Spanish coeliac children using the generic KIDSCREEN-52 questionnaire. Eur. J. Pediatr., 177 (10), 1515-1522.

Bompori, E., Niakas, D., Nakou, I., Siamopoulou-Mavridou, A., Tzoufi, M. S. (2014). Comparative study of the health-related quality of life of children with epilepsy and their parents. Epilepsy Behav., 41, 11-17.

Centers for Disease Control and Prevention (2011). Health-related quality of life. https://www.cdc.gov/hrqol/concept.htm (accessed 13.02.2019).

Constitution of the World Health Organization. 1946 (2002). Bulletin of the World Health Organization, 80 (12), 983.

https://www.who.int/about/mission/en/ (accessed 13.02.2019).

Eiser, C., Varni, J. W. (2013). Health-related quality of life and symptom reporting: Similarities and differences between children and their parents. Eur. J. Pediatr., 172 (10), 1299-1304.

Haraldstad, K., Christophersen, K. A., Eide, H., Nativg, G. K., Helseth, S. (2011). Health related quality of life in children and adolescents: Reliability and validity of the Norwegian version of KIDSCREEN-52 questionnaire, a cross sectional study. Int. J. Nursing Studies, 48 (5), 573-581

Jaimes-Valencia, M. L., Perpiñá-Galvañ, J., Cabañero-Martínez, M. J., Cabrero-García, J., Richart-Martínez, M. (2019). Adjusted linguistic validation and psychometric properties of the Colombian version of KIDSCREEN-52. J. Child Health Care, 23 (1), 20-34.
Jiménez-Iglesias, A., Moreno, C., Ramos, P., Rivera, F. (2015). What family dimensions are important for health-related quality of life in adolescence? J. Youth Studies, 18 (1), 53-67.

Karimi, M., Brazier, J. (2016). Health, health-related quality of life, and quality of life: What is the difference? Pharmacoeconomics, 34 (7), 645-649.

KIDSCREEN Group (2004). Description of the KIDSCREEN-27. Health-related quality of life questionnaire for children and young people short version.

http://www.mentalhealthpromotion.net/resources/kidscreen-27_description.pdf (accessed 12.09.2021)

Ravens-Sieberer, U., KIDSCREEN Group Europe (2006). The KIDSCREEN questionnaires - quality of life questionnaires for children and adolescents. Handbook. Pabst Science Publishers, Lengerich, pp. 323-340.

Kliegman, R., Stanton, B., St. Geme, J. W., Schor, N. F., Behrman, R. E. (2016). Nelson Textbook of Pediatrics (edn. 20). Elsevier, Philadelphia, PA. Chapter 1, pp. 1-18.

Kontodimopoulos, N., Damianou, K., Stamatopoulou, E., Kalampokis, A., Loukos, I. (2018). Children's and parents' perspectives of health-related quality of life in newly diagnosed adolescent idiopathic scoliosis. $J$. Orthopaed., 15 (2), 319-323.

Meade, T., Dowswell, E. (2015). Health-related quality of life in a sample of Australian adolescents: Gender and age comparison. Quality of Life Res., 24 (12), 2933-2938.

Michel, G., Bisegger, C., Fuhr, D. C., Abel, T. (2009). Age and gender differences in health-related quality of life of children and adolescents in Europe: A multilevel analysis. Quality of Life Res., 18 (9), 1147-1157.

Ravens-Sieberer, U., Gosch, A., Rajmil, L., Erhart, M., Bruil, J., Duer, W., Auquier, P., Power, M., Abel, T., Czemy. L., Czimbalmos. A., Tountas, Y., Hagquist, C., Kilroe, J., Mazur, J. (2005). KIDSCREEN-52 quality-of-life measure for children and adolescents. Expert Rev. Pharmacoecon. Outcomes Res., 5 (3), 353-364.

Ravens-Sieberer, U., Herdman, M., Devine, J., Otto, C., Bullinger, M., Rose, M., Klasen, F. (2014). The European KIDSCREEN approach to measure quality of life and well-being in children: Development, current application, and future advances. Quality of Life Res., 23 (3), 791-803.

Taliep, N., Florence, M. (2012). Evaluating the construct validity of the KIDSCREEN-52 Quality of Life questionnaire within a South African context. South Afr. J. Psychol., 42 (2), 255-269.

Theunissen, N. C. M., Vogels, T. G. C., Koopman, H. M., Verrips, G. H. W., Zwinderman, K. A. H., Verloove-Vanhorick, S. P., Wit, J. M. (1998). The proxy problem: Child report versus parent report in health-related quality of life research. Quality of Life Res., 7 (5), 387-397.

\section{VESELO BĒRNU DZĪVES KVALITĀTE LATVIJĀ}

Latvijā pētījumi par veselo bērnu dzīves kvalitāti nav veikti. Bērnu dzīves kvalitātes noteikšana ir būtiska bērnu veselības stāvokḷa izvērtēšanas sastāvdaḷa. Iegūstot bērna vai pusaudža subjektīvu vērtējumu par dzīves kvalitāti, rodas iespēja izvērtēt populācijas dzīves kvalitāti sabiedrības veselības nozarē. Šḳērsgriezuma pētījuma mērḳis bija izvērtēt veselo bērnu un pusaudžu dzīves kvalitāti Latvijā vecuma grupā no 8 līdz 18 gadiem, kā arī salīdzināt ar vecāku/aizbildṇu sniegtajām atbildēm, vērtējot pēc "KIDSCREEN-52" anketas rezultātiem. Pētījumā piedalījās 100 veseli bērni/pusaudži un vinu vecāki/aizbildṇi. Ar veselību saistītās dzīves kvalitātes aptauja sastāvēja no desmit dimensijām. Izvērtējot bērnu un pusaudžu dzīves kvalitāti Latvijā atkarībā no dzimuma, netika konstatēta statistiski nozīmīga atšķirība $(p>0,05)$. Salīdzinot sniegtās atbildes vecuma katogorijās, konstatēta statistiski būtiska atšķirība starp 8 līdz 11 un 12 līdz 18 gadus jauniem, veseliem bērniem Latvijā divās no desmit dimensijām — par sevi ("SEL") un vispārējais garastāvokis ("EMO") uzrādīja statistiski nozīmīgas atškirības $(p<0,05)$, norādot, ka pusaudži vecumposmā no 12 līdz 18 gadiem dzīves kvalitāti vērtē augstāk, nekā bērni vecuma grupā no 8 līdz 11 gadiem. Bērnu/pusaudžu dzīves kvalitātes aptaujas rezultāti, salīzinot starp Latvijas un Eiropas sniegtajiem rezultātiem, neuzrādīja statistiski ticamu atškirību visās desmit dimensijās $(p>0,05)$. 